\title{
AZ ELEKTRODINAMIKUS ALAKÍTÁS ALKALMAZÁSI LEHETŐSÉGEI
}

\section{POSSIBLE APPLICATIONS OF ELECTRODYNAMIC FORMING}

\author{
Rácz Pál
}

Óbudai Egyetem, Bánki Donát Gépész és Biztonságtechnikai Mérnöki Kar, Anyagés Gyártástudományi Intézet, Magyarország, 1083 Budapest, Népszínház utca, 8; Telefon: +36-1-6665430,racz.pal@bgk.uni-obuda.hu

\begin{abstract}
Two types of electrodynamic forming have been evolved; the electromagnetic and the electrohydraulic forming. At electromagnetic process the electrical energy stored in the capacitor bank discharges through a coil, resulting in electrical interaction between the coil and the workpiece causing deformation of the workpiece. At electrohydraulic forming the energy stored in the capacitor bank discharges through a metal wire or a spark gap, creating shock waves in a transfer medium to change the shape of the workpiece. High deformation rates occur, and significant deformations can be created by these processes. The electromagnetic and electrohydraulic methods can be used in many areas of shaping metallic and non-metallic materials. This paper discusses these application areas, such as expansion or compression forming of tubular parts, flat sheets, joining, and assembly operations.
\end{abstract}

Keywords: electrodynamic forming, electromagnetic forming, electrohydraulic forming.

\section{Összefoglalás}

Az elektrodinamikus alakítás két típusa alakult ki; az elektromágneses alakítás, és az elektrohidraulikus alakítás. Az elektromágneses alakításnál a kondenzátortelepben tárolt energia egy tekercsen keresztül sül ki, a tekercs és az alakítandó munkadarab közötti villamos kölcsönhatás eredményezi a munkadarab alakváltozását. Az elektrohidraulikus alakításnál a kondenzátortelepben tárolt energiát szikraközön vagy fémhuzalon keresztül sül ki, a kisütési folyamat által egy átadó közegben keltett lökéshullámok hatására alakváltozik a munkadarab. Nagy alakváltozási sebességek alakulnak ki, jelentős alakváltozások hozhatóak létre ezekkel az eljárásokkal. Az elektromágneses és az elektrohidraulikus alakítások számos területen alkalmazhatók fémes és nem fémes anyagok alakítására. A cikk bemutatja ezeket az alkalmazási területeket, mint például a cső alakú alkatrészek expanziós, vagy kompreszsziós alakítása, sík lemezek alakítása, kötési, szerelési műveletek elvégzése.

Kulcsszavak: elektrodinamikus alakitás, elektromágneses alakitás, elektrohidraulikus alakitás.

\section{Elektromágneses alakítási pél- dák}

Az elektromágneses eljárás a kifejezetten alakítási müveletekhez képest nagyobb jelentőségü a képlékeny-alakítással létesített mechanikus kötések, vagyis a szerelés területén. A szerelési müveletek azonban nemcsak a hagyományos értelemben vett szerelések helyettesítésére szolgálnak, hanem bizonyos esetekben új, egyszerübb, olcsóbb konstrukciós lehetőségeket is nyújtanak. A csatlakozó elemeken olyan hornyok, beszúrások, vállak kiképzése szüksé- 
ges, amelyek az összeszerelt alkatrészek megfelelő mechanikus kötését biztosítják [1] (1. ábra).

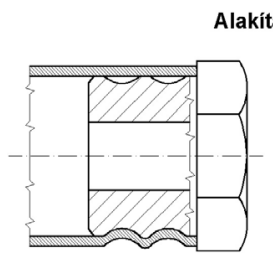

Alakítás előtt

a.

Alakítás után

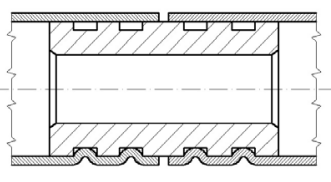

b.

1. ábra. Alakzáró kötések

Torziós igénybevétel átvitelére (pl. tengelyeknél) hosszanti bordázattal célszerü ellátni a csatlakozó darabot, és az alakított darabot a bordák közé sajtoljuk be [2] (2. ábra).

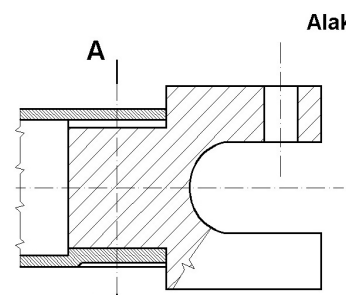

Alakítás elött

A

Alakítás után

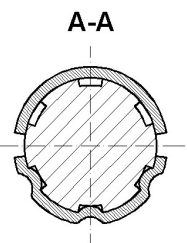

2. ábra. Tengelyvégzödés hosszanti bordázattal

Különféle edények, hengerek, csőlezárások alakíthatók ki viszonylag egyszerü módon, megfelelően kiképzett végdarabokkal. A 3. ábrán tömítőanyag nélküli (a.), és O-gyürü alkalmazásával kialakított (b.) csőlezárások láthatók.

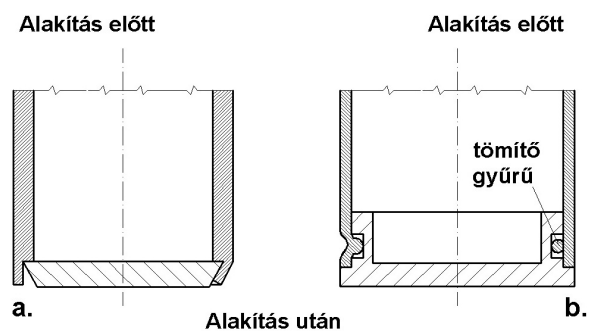

3. ábra. Különféle kialakitású csőelzárások
Számos olyan eset fordul elö, amikor a kívánt szerelési müveletet egy újabb elem felhasználásával lehet létrehozni. Ilyen esetekben általában gyürü alakú darabot, egy rövid csődarabot használnak, mellyel körülveszik az összeszerelendő alkat-részeket és a gyürü, alakítás után, mint bilincs rögzíti azokat. A gépjármüiparban használatos porvédö gumi harangok szerelésekor is alkalmazható ez a megoldás (4. ábra).

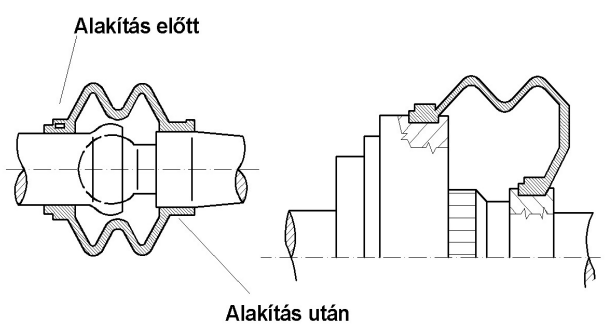

4. ábra. Gumiharangok szerelése

Hasonlóan az előző példához, gumitömlők, nagynyomású hidraulikus vezetékek csatlakozó elemei szerelhetők lemezbilincs helyett csőgyürükkel. A gyürü a tömlőben fellépő nyomás szerint méretezhető, ily módon biztos kötést lehet létesíteni. Vizsgálati adatok szerint vászonbetétes, acélfonattal páncélozott, nagynyomású gumitömlők próbanyomásnál mindig elöbb széthasadtak, semmint a csőgyürüvel, elektromágneses alakítással rögzített végződés szivárgott volna (5. ábra).

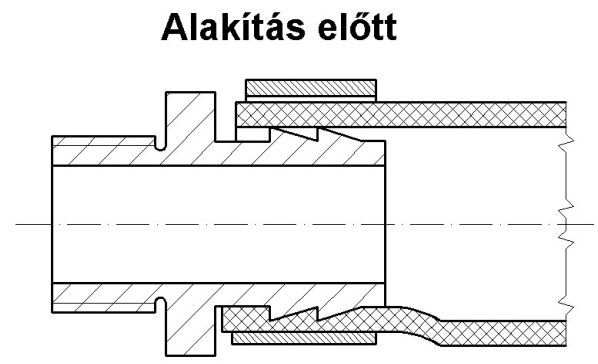

\section{Alakítás után}

5. ábra. Gumitömlő csatlakozó szerelése 
Szerszámban való alakításkor a munkadarab alakját az alakító matrica vagy betét határozza meg oly módon, hogy az alakítandó profilt a szerszámba bemunkálják. Kisebb igénybevételek és kisebb darabszámok esetén a szerszám lehet müanyag, vagy esetleg fából is készülhet, nagyobb sorozatoknál és nagyobb igénybevételeknél általában fém, főleg acél szerszám használható. Edzett acél betétek alkalmazása lyukasztó és kivágó müveleteknél célszerü. Amennyiben a matrica felülete nem zárt, hanem azon kivágás vagy lyukasztás céljára kiképzett furat van, akkor ilyen jellegü müveleteket végezhetők jó vágási felületminőséggel. A 6. ábrán látható egy csődarab szükítő alakításával kombinált lyukasztás. A szükítő alakítás a csődarabot kúpos átmenetüre képezi ki.

\section{Alakítás után}

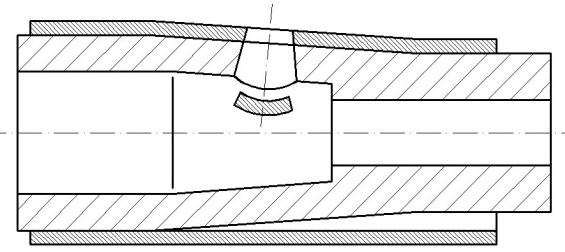

Alakítás előtt

6. ábra. Kúpos szükitéssel kombinált lyukasztás

\section{Elektrohidraulikus alakítási példák}

$\mathrm{Az}$ elektrohidraulikus alakítás jellegzetes müveletei: üreges darabok tágítása, kalibrálása, vágása, lyukasztása, továbbá mélyhúzás jellegü müveletek és esetenként különleges kötések, szerelések megvalósítása. A nyomásátadó közeg folyadék, legtöbbször víz, a folyadék tartály zárt. Ez azt eredményezi, hogy a nyomáshullám jól hasznosítható és megfelelöen irányítható. Huzal elgőzölögtetéses módszerrel a lökéshullám nyomásintenzitását is az alakítandó munkadarab alakja szerint lehet változtatni. A zárt folyadéktérben elhelyezett reflektor- felületek extrém alakítási müveleteket is lehetővé tesznek [3]. A 7. ábra bal oldalán olyan csődarab alakításának vázlata látható, ahol a cső átmérőjének és hosszának viszonya 0,1-nél kisebb, az ábra jobb oldalán pedig 7 az arány. Mindkét esetben a reflektorbetét tereli a lökéshullámokat.

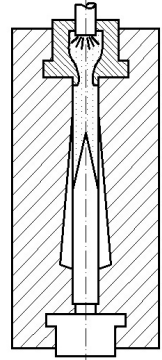

a.

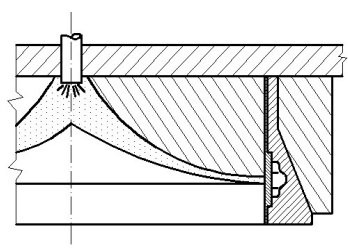

b.
7. ábra. Reflektoros alakitású szerszámok

Az elektrohidraulikus alakítás sokoldalú alkalmazási lehetőségeinek jellemzésére a következő ábrák olyan jellegzetes alkatrész típusokat mutatnak be, melyek alapján megítélhető, milyen geometriai alakzatok alakíthatók. A 8. ábrán különböző tágítási müveletek szerepelnek.
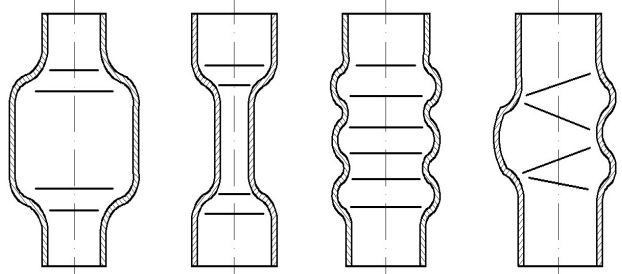

8. ábra. Tágítással alakitott alkatrészek

A 9. ábrán ugyancsak tágítási müveletek láthatók vágással és lyukasztással kombinálva. A vágást vagy szétválasztást azon a szakaszon célszerü végezni, ahol az alakítási müvelet folyamán a munkadarab anyaga a lökéshullám hatására nagy alakítási sebességet ér el. 

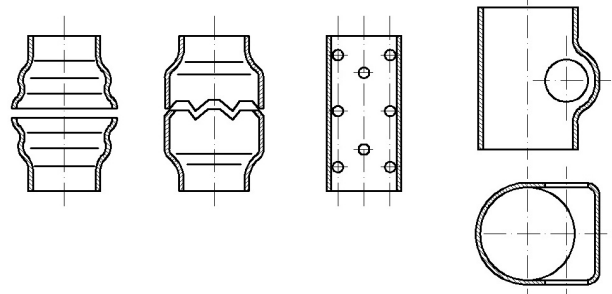

9. ábra. Tágitással alakitott és lyukasztással, vágással, kombinált alkatrészek

Sík lemeztárcsából mélyhúzás jelleggel alakított alkatrészek láthatók a 10. ábrán.
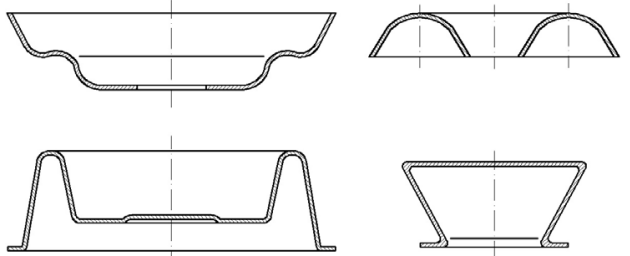

10. ábra. Sík lemeztárcsából készült alkatrészek

Bizonyos esetekben speciális szerelési müveletek is végezhetők elektrohidraulikus alakítással. A 11. ábrán két alkatrész összeszerelése látható szilárd (a.) és mozgó (b.) kötéssel.
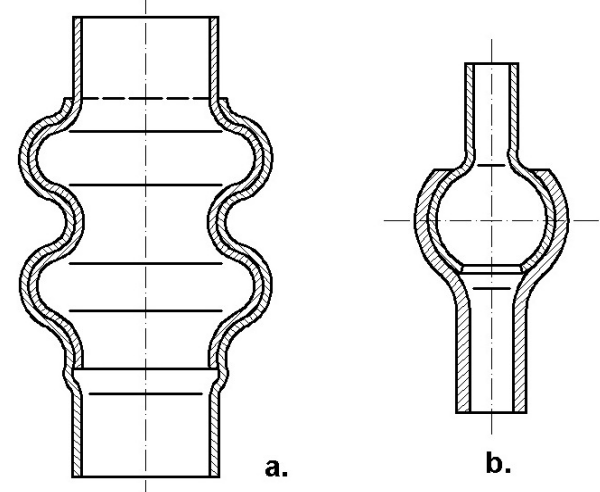

11. ábra. Szerelés szilárd és mozgó kötéssel

Az elektrohidraulikus alakításra bemutatott eddigi példák főleg nagyobb alakítási mértékkel formált darabokra vonatkoznak.
Sok esetben célszerü az eljárás alkalmazása akkor is, ha viszonylag kis alakítási mértékkel kell speciális formákat kialakítani vagy kalibrálni. Üreges darabok, például dísztárgyak palástjának mintázása is jó eredménnyel végezhetö, erre különösen olyan esetekben van lehetőség, amikor a kiinduló darab olyan alakú, hogy az elektromágneses alakító tekercs kontúrjával nem követhető. Serlegek és más hasonló, felületükön cizellálással díszített alkatrészek mintázását lehet kézi megmunkálás helyett gépesíteni. Ilyen esetekben a mintázatot a matricába kell bemunkálni.

\section{Következtetések}

Az elözőekben bemutatott ábrákból is kitünik, hogy az elektrodinamikus alakító eljárások alkalmazása az alábbi felhasználási területeken indokolt:

- csőalakú előgyártmány expanziós vagy kompressziós alakítása, lyukasztása, kivágása, peremezése;

- lemezalakú előgyártmányok viszonylag kis alakítási mélységü alakítása;

- csőalakú előgyártmánnyal expanziós vagy kompressziós jellegü szerelési müveletek elvégzése.

\section{Szakirodalmi hivatkozások}

[1] Rácz, P., Göbl, N., Horváth, D.: Rúd-cső kötések készitése elektromágneses alakitással. XIV. Képlékenyalakító Konferencia, Miskolci Egyetem, Miskolc, 2012, 75-81.

[2] Rácz, P.: Csavaró igénybevételnek ellenálló elektromágneses kötések. Műszaki Tudományos Füzetek, EME kiadó, Kolozsvár, 2014, 331-344.

[3] Rácz, P., Göbl, N., Horváth, D., Mamalis, A. G.: Electrodynamic Forming Processes. Materials Science Forum, Vol. 767. Trans Tech Publication Ltd. Switzerland, 2014, 126-131. 